\title{
Profesor Rudolf Šrámek slaví 85. narozeniny
}

Z krajiny dětství a mládí si odnášíme do života největší míru znalosti zeměpisných jmen konkrétní lokality, kterou později obvykle již žádné další místo intenzitou svého „toponymického“ působení nepřekoná. Podíváme-li se na tento vztah z opačné perspektivy, pak se také každý člověk aktivně podílí na obohacování lokální toponymie, byt často jde o pojmenování sociálně nebo generačně determinovaná, jež mizí z prostoru beze stopy s odchodem jedince nebo jeho generace. Vzácně se však stane, že rodný kraj a člověk se prostřednictvím jazyka a toponymie dlouhodobě formují a ovlivňují navzájem, a tento obapolný vztah dokonce zanechá svůj odraz v krajině psaného textu veřejného prostoru. Taková štastná symbióza se vytvořila v případě letošního jubilanta, profesora Rudolfa Šrámka a jeho rodného kraje.

Rudolf Šrámek se narodil 15. 1. 1934 v tehdy nedávno otevřeném porodnickém pavilonu ostravské Státní všeobecné veřejné nemocnice nacházející se v katastru Zábřehu nad Odrou (dnes součást Ostravy). Tato okolnost způsobila, že má v rodném listu zapsáno jako rodiště Zábřeh, nikoliv na druhém břehu ležící Hoštálkovice (dnes rovněž součást Ostravy), kde prožil své dětství a mladá léta a kam se stále rád vrací. Dodnes s rozechvělým hlasem a zápalem v očích vypráví o místech, jejichž názvy vyvolávají vzpomínky na jeho mládí. Mnohá z těchto pojmenování již zmizela - místa byla zastavěna, krajinu u Odry zjizvila dálnice, řada jmen byla zcela zapomenuta. Avšak zájem, který ve vnímavém „haviřskem synkovi“ vzbudily názvy jako Bona, Strubisko, Opa, Firek, U paryzola nebo Červene břehy, již nezmizel. Spolu s citlivostí k jazyku, nepochybně danou rovněž mnohojazyčnou situací rodného Hlučínska, si tak Rudolf Šrámek odnesl vynikající základ pro svou další badatelskou práci, již spojil s brněnskou univerzitou a částečně také s univerzitou v Ostravě. Jeho bibliografie čítá stovky studií a konferenčních vystoupení, desítky monografií, kapitol a recenzí (viz TuškoVÁ - KolÁřová 2008). Výzkumy profesora Šrámka oborově a tematicky pokrývají obecnou lingvistiku, slavistiku, onomastiku a dialektologii, pokud mám zmínit klíčové oblasti jeho odborného zájmu. Šrámkovy texty svědčí o mimořádné schopnosti analyzovat jazykový materiál a formulovat obecné teorie, překonávat hranice mezi disciplínami a používat interdisciplinární a multidisciplinární přístupy k jazyku, ale současně pamatují rovněž na učitele češtiny i laického čtenáře zajímajícího se o jazykovědu. Nechci detailně podávat výčet jubilantových prací a hodnotit jeho př́nos na poli jazykovědy - to již přede mnou učinili jiní (např. BAYEROVÁ - LUTTERER 1994; KNAPPOVÁ 1993-1994; HARVALÍK 2004, 2016; KOMÁREK 2004; OBROVSKÁ 2004; WACLAWIČOVÁ - ŠRÁMEK 2010; MINÁŘovÁ 2014; VÁLKA 2014; DVOŘÁK 2016; ZÁřICKÝ 2016). Přesto je třeba připomenout aspoň ty základní - dvojdílná Místní jména 
na Moravěa ve Slezsku (1970, 1980, společně s L. Hosákem) doplněná o Retrográdní slovník místních jmen Moravy a Slezska (2013), Úvod do obecné onomastiky (1999), Beiträge zur allgemeinen Namentheorie (2007), Zeměpisná jména Československa (1982, s I. Luttererem a M. Majtánem), později jako Zeměpisná jména Čech, Moravy a Slezska (1997, 2004, s I. Luttererem); z posledních let Jména obcí a sídel na Hlučínsku (2013) a soubor studií Labyrintem vlastních jmen a nářečí (2016).

V úvodu jsem připomněl obapolný vztah mezi toponymií místa a jejím uživatelem. Chtěl bych ještě několik slov věnovat tomu, co se podaří jen málokterému lingvistovi, totiž aby toponymii v lokalitě spojené s jeho životem nejen studoval, ale opravdu „zhmotnil“ v jejím prostoru. Mám tím na mysli jedinečný soubor uličních názvů, který vznikl v polovině sedmdesátých let. Hoštálkovice byly tehdy připojeny k Ostravě a Rudolf Šrámek byl osloven, aby vytvořil systém uličních jmen. Jeho podmínkou bylo, aby nové názvy neobsahovaly žádná honorifikační pojmenování a co nejvíce odrážely charakter místa. Uprostřed normalizace, v letech 1976-1978, byla vytvořena soustava uličních jmen navazujících na stará pojmenování místních částí a původní pomístní názvy, např́ílad Aleje, Mezi Ploty, Rynky, Vrbiny, Za Hřbitovem, nebo vycházejících z charakteru místa, například Dlážděná, Ořechová, Př́krá. Hoštálkovický urbanonymický soubor vyrůstá z lokální názvoslovné tradice a uchovává ji navzdory lidskému zapomínání jako stále živou.

Ačkoliv profesor Šrámek letos v lednu oslavil již úctyhodné 85. narozeniny, je stále plný životní energie a zájmu o obor. Svědčí o tom nejen jeho aktivní působení coby recenzenta odborných článků, monografií i dizertačních prací, vystoupení na domácích a zahraničních konferencích, ale také živé a inspirativní přednášky a diskuze, v nichž má stále co říci.

Milý pane profesore, před dvaceti lety jsem ještě jako začínající a naivní doktorand měl čest se s Vámi coby mým školitelem poprvé osobně setkat. Musím říct, že to bylo pro mě nejen setkání štastné, ale i osudové a zásadní. $Z$ doby doktorských studií i pozdějš́ch let jsem si odnesl řadu zásad pro svoji další badatelskou i učitelskou práci. Patřŕ k nim vstř́ícnost, otevřenost a kladení si otázek, zájem o živý jazyk a jeho používání, vědomí důležitosti učitelské práce a popularizace i důraz na mezinárodní povahu vědy a její prezentace. A vlastně se stále od Vás učím a inspiruji. Jako žák i kolega děkuji. A přeji Vám k letošnímu životnímu jubileu pevné zdraví, neutuchající badatelskou zvědavost a zvídavost a hodně milých setkání.

\section{LITERATURA}

BAYEROVÁ, Naděžda - LUTTERER, Ivan. 1994. Rudolf Šrámek šedesátiletý. Naše řeč 77, 106-108. DvořÁk, Jan. 2016. Rudolf Šrámek a významná jména „bez významu“. In: Labyrintem vlastních jmen a nářeči. Brno: Host, 9-10.

HARVALÍ́, Milan. 2004. K životnímu jubileu Rudolfa Šrámka. Acta onomastica 45, 154-158. HaRvaLík, Milan. 2016. K životnímu jubileu Rudolfa Šrámka. Acta onomastica 55, 387-390. KoMÁreK, Karel. 2004. Rudolf Šrámek sedmdesátiletý. Jazykovědné aktuality 41, 56-57. KnAPpová, Miloslava. 1993-1994. Rudolf Šrámek sedmdesátiletý. Onomastický zpravodaj 34-35, 183-185. 
MinÁŘová, Eva. 2014. Rudolf Šrámek a onomastika. In: Vlastní jména v textech a kontextech. Brno: Masarykova univerzita, 9-11.

OBrovská, Jana. 2004. Profesoru Rudolfu Šrámkovi k narozeninám. Naše řeč 87(3), 156-159. TušKovÁ, Jana Marie - KoláŘová, Ivana. 2008. Bibliografie Rudolfa Šrámka za léta 1956-2008. Brno: Masarykova univerzita.

VÁLKA, Miroslav. 2014. Přání k životnímu jubileu filologa Rudolfa Šrámka. Národopisná revue 24, 326-327.

WACLAWIČovÁ, Martina - ŠRÁMEK, Rudolf. 2010. Rozhovor s prof. PhDr. Rudolfem Šrámkem, CSc. In: Rozhovory s českými lingvisty 3. Praha: Akropolis, 247-286.

ZÁřickÝ, Aleš. 2016. Laudatio u př́ležitosti udělení titulu doctor honoris casa prof. PhDr. Rudolfu Šrámkovi, CSc. Bohemistyka 16, 189-191.

Jaroslav David

Department of Czech Language

Faculty of Arts, University of Ostrava

702 oo Ostrava

Czech Republic

jaroslav.david@osu.cz 
